\title{
A Quantitative Study of the Relationship between Distributed Leadership and Organizational Citizenship Behavior: Perceptions of Turkish Primary School Teachers
}

\author{
Ali Çağatay Kılınç,** \\ ${ }^{1}$ Department of Educational Sciences, Faculty of Letters, Karabuk University, Karabuk, Turkey \\ ${ }^{*}$ Correspondence: Karabuk University Iron and Steel Campus, 78050, Karabuk, Turkey. Tel: 90-370-433-82-94. \\ E-mail: cagataykilinc@karabuk.edu.tr
}

Received: June 14, $2014 \quad$ Accepted: July 9, $2014 \quad$ Online Published: July 28, 2014

doi:10.5430/jct.v3n2p69 URL: http://dx.doi.org/10.5430/jct.v3n2p69

\begin{abstract}
The purpose of this study was to determine the relationship between primary school teachers' perceptions on distributed leadership and organizational citizenship behaviors (OCBs). A total of 258 teachers employed in 14 primary schools located in Kastamonu, Turkey participated in this study. Data of the study was collected through "Distributed Leadership Scale" and "Organizational Citizenship Behavior Scale". Descriptive statistics, Pearson product-moment correlation coefficient and simple regression analysis were used to analyze the study data. Findings of the current study revealed that primary school teachers' perceptions of distributed leadership was positively and significantly related to teacher OCBs. Furthermore, distributed leadership was a positive and significant predictor of teacher OCBs. Results of the study were discussed in relation to practical implications in school settings.
\end{abstract}

Keywords: distributed leadership; organizational citizenship; primary school; teacher

\section{Introduction}

Teachers play a critical role in the designation, implementation, and evaluation of the most effective classroom practices for student learning and achievement (Harris and Lambert, 2003; Tsui and Cheng, 1999). In this regard, $\mathrm{OCB}$ is one of the constructs that has continued to interest scholars, practitioners, and policy-makers to influence school effectiveness and improvement (Feather and Rauter, 2004; Nguni et al., 2006; Oplatka, 2006; Organ, 1988, 1997; Ölçüm-Çetin, 2004; Paine and Organ, 2000; Podsakoff et al., 2000; Sezgin, 2005). Teacher OCBs are crucial for schools as the construct relates to non-formally prescribed behaviors including teachers' exerting extra effort and time and taking the responsibility of school improvement individually (Hoy et al., 1991; Somech and Ron, 2007). It is therefore reasonable to suggest that there is a need for further studies investigating the relationship between OCB and other organizational and individual characteristics to contribute to a better understanding of the construct and to make practical implications for practitioners and policy-makers. As pointed out by DiPaola and Tschannen-Moran (2001), principals, teachers, and policy-makers will benefit from research on investigating and learning the variables that foster teacher OCBs to improve and sustain student achievement.

Teachers giving extra time and effort for student learning have an influence on building a high quality of school environment (DiPaola and Tschannen-Moran, 2001). Evidence from the related literature highlights that teacher OCBs were associated with school climate (DiPaola and Tschannen-Moran, 2001), organizational identification (Christ et al., 2003; van Dick et al., 2006), student achievement (DiPaola and Hoy, 2005), burnout (Chiu and Tsai, 2006; Emmerik et al., 2005; Schepman and Zarate, 2008; Sezgin and Kilınç, 2012), organizational commitment (Feather and Rauter, 2004), school administrators' organizational power sources (Altınkurt and Y1lmaz, 2012), organizational justice (Moorman, 1991), perceived superior support (Somech and Ron, 2007), and perception of empowerment (Bogler and Somech, 2004). School principals' leadership style has been one of the organizational constructs potentially influencing teacher OCBs. Several studies have investigated OCBs in relation to such different leadership styles as transformational (Lian and Tui, 2012; López-Domínguez et al., 2013; Podsakoff et al., 1990; Podsakoff et al., 1996; Song et al., 2012), transactional (Lian and Tui, 2012; Nguni et al., 2006), servant (Bobbio et 
al., 2012), and charismatic leadership (Cavazotte et al., 2014). These studies typically adopted a principal-focused approach which regards leadership as an individual property instead of an organizational one (Hulpia et al., 2010). Recent years, however, have witnessed a shift in leadership paradigms from single-person or heroic leadership which places the responsibility of leading school processes only the accounts of school principals (Gronn, 2000; Harris, 2004; Harris and Lambert, 2003; Harris and Spillane, 2008; Spillane, 2005) and which restricts leadership to one person (Harris et al., 2007) to a distributed, dispersed or shared leadership approach (Gronn, 2000, 2009a, 2009b; Harris, 2004; Harris and Spillane, 2008; Spillane, 2005; Spillane et al., 2003). Recent leadership approaches suggest that leadership is an organizational process (Ogawa and Bossert, 2000) and that each member of the organization should have the right and the responsibility to skillfully participate in school leadership practices (Harris and Lambert, 2003). However, research on the relationship between OCB and distributed or shared leadership remains extremely thin (Jofreh et al., 2012). Hulpia et al. (2010) further argue that there is lack of evidence concerning the effects of distributed leadership on organizational qualities. It is also reasonable to suggest that the relationship between OCB and distributed leadership still remains unexplored. Therefore, the current study was conducted to supplement this niche in the literature by investigating the correlational and predictive relationships between distributed leadership and teacher OCBs.

Findings of the current study may well contribute to a better understanding of the organizational citizenship construct by investigating its relationship with distributed leadership. It is also expected that this study may provide policy-makers, practitioners, and educational researchers with important implications to promote teacher OCBs in schools. In this sense, the present study aims at addressing the following questions:

a) Are there significant correlations between OCB and distributed leadership?

b) Is the construct of distributed leadership a significant predictor of OCB?

\subsection{Organizational Citizenship Behaviors}

Organizational citizenship is one of the few individual variables that influence organizational effectiveness (Bogler and Somech, 2004; Nguni et al., 2006; Oplatka, 2006; Organ, 1988; 1997; Paine and Organ, 2000; Podsakoff et al., 1990; Podsakoff et al., 1996, Podsakoff et al., 2000; Somech and Drach-Zahavy, 2004). The concept of OCB draws primarily upon Chester Barnard's concept of 'willingness to change' and Daniel Katz's notion of 'distinction between dependable role and performance' and 'innovative and spontaneous behaviors' (Podsakoff et al., 2000, p. 513). Organ (1988) defined the construct of OCB as "an individual behavior that is discretionary, not directly or explicitly recognized by the formal reward system, and that in the aggregate promotes the effective functioning of the organization" (p. 4). Oplatka (2006) points out that OCBs are those that are not a part of employees' job description and are not directed at receiving organizational rewards. Furthermore, a range of scholars argue that OCB refers to a willingness to assume extra role behaviors (Feather and Rauter, 2004), helping colleagues without an expectation of a quick response (Nguni et al., 2006), and individual behaviors "performed with the intention of promoting the welfare of the individual, group, or organization toward which it is directed." (Oplatka, 2006, p. 389).

Organ $(1988,1997)$ offers five dimensions of OCB (altruism, conscientiousness, sportsmanship, courtesy, and civic virtue) and explains their contribution to organizational effectiveness. Altruism refers to assisting individuals in the organization including colleagues, associates, or clients which promotes individual capacity and thereby organizational improvement. Helping new colleagues and exerting time and effort on improving others' capacities are regarded as various forms of altruism (Ölçüm-Çetin, 2004). Conscientiousness denotes to employees' going beyond job expectations. Conscientious behaviors include employees' using their working time effectively and being obedient to certain rules of the organization (Organ and Lingl, 1995). Sportsmanship is associated with avoiding complaining about unsuitable or inconvenient issues, which probably leads the employee to focus more on core purposes of the organization. Courtesy is related to building a proper and an effective way of communication. Courteous employees are expected to keep in touch with those who will probably be affected by certain decisions or behaviors before acting (Schnake and Dumler, 2003), and to give information about the recent amendments in their work programs (Organ, 1988). Civic virtue refers to employees' willingness to actively participate in and contribute to the management of the organization.

OCBs regarded as extra-role behaviors which are non-prescribed and non-formally generated are important for the effective functioning of the organization (DiPaola and Tschannen-Moran, 2001). Therefore, the construct of OCB has recently attracted the attention of educational scholars (e.g. Bogler and Somech, 2004; DiPaola and Hoy, 2005; DiPaola and Tschannen-Moran, 2001; Feather and Rauter, 2004; Nguni et al., 2006; Oplatka, 2006; Somech and Ron, 2007). Drawing upon empirical evidence from these studies, it is reasonable to argue that teacher OCBs are crucial for the effective functioning and sustainable improvement of schools. Because teachers demonstrating OCBs help 
inexperienced teachers to improve their teaching skills, exert extra effort and time to design and implement effective classroom practices, participate in the school-management related activities such as meetings, arrangements, and committees, work with colleagues to reflect on instructional issues, and offer practical solutions to challenging problems (DiPaola and Tschannen-Moran, 2001). Clarifying the role of OCBs for schools, Bogler and Somech (2004) assert that teacher OCBs reflect the technical core of the school as such teachers produce special classroom practices for both high and low-achieving students, lead instructional innovations, and enlarge their knowledge and expertise in their field.

As stated by DiPaola and Hoy (2005), teachers are professionals who are required to make professional decisions and committed to the such core functions of the teaching profession as serving best to students by designing and implementing effective classroom practices. It is therefore arguable that teachers as professionals may have tendency to go beyond their formal role descriptions to best serve to meet the diverse needs of students. In this regard, teacher OCBs may be considered as an important part of overall school performance and a high level of student achievement. Furthermore, Oplatka (2006) suggests that schools can benefit from research on OCBs as investigating teacher OCBs may help to distinguish formal roles and regulations from extra-role behaviors.

\subsection{Distributed Leadership}

Distributed leadership has recently attracted the attention of scholars, practitioners, and policy-makers to promote school improvement (Harris and Lambert, 2003; Harris and Muijs, 2005; Spillane, 2005; Spillane et al., 2003). Traditional leadership notions heavily premise upon the accounts of an individual who manages the system or structures (Harris, 2004). Recent times, however, have witnessed a shift from traditional leadership approaches to professionally-oriented and decentralized forms of leadership (Fullan, 2001). One such alternative notion is distributed leadership which is argued to present a new way of examining and transforming school leadership practices (Spillane et al., 2001). It is what Elmore (2000) terms "a redefinition of leadership, away from role-based conceptions and toward distributive views" (p. 35).

Distributed leadership refers to "a form of collective leadership in which teachers develop expertise by working together" (Haris, 2004, p. 4). Spillane (2006) suggests that the construct of distributed leadership includes two main perspectives: the leader-plus and the practice. The leader-plus perspective offers that the process of school administration comprises of multiple individuals apart from those in formal roles such as school principal, assistant principals, and specialists. The leadership practice perspective, on the other hand, focus primarily on the practice of leading which allows others without designated formal roles to contribute to and participate in school leading actions. Spillane further argues that the leadership practices are performed though interaction among colleagues. In this sense, extending the boundaries of leadership to individuals and taking the "broad-based and skillful involvement" of teachers into account (Harris and Lambert, 2003, p. 13), distributed leadership is an "emergent property of a group or network of interacting individuals" (Bennett et al., 2003, p. 7) who make well use of colleagues' knowledge, disposition, and expertise (Gronn, 2000) and who help colleagues improve the classroom practices to support sustainable school improvement (Harris, 2008).

Harris and Spillane (2008) offer three basic reasons for explaining the rising popularity of the distributed form of leadership. First, the construct of distributed leadership has normative power which denotes that this kind of leadership presents the current changes in the practice of leadership that shifts from "heroic leadership" (Hargreaves and Fink, 2009, p. 184) regarding the school principal as "chief doer" (Lashway, 2003, p. 3) and leadership as a "role" (Harris and Spillane, 2008, p. 33) to collaborative leadership teams (Harris, 2004, 2008) which promotes the "openness of the boundaries of leadership" (Bennett et al., 2003, p. 7). Second, distributed form of leadership has representative power as it stands for alternative leadership forms (Harris and Spillane, 2008). In line with this argument, Harris and Lambert (2003) point out that school improvement and change processes are not likely to be achieved effectively by simply centering upon individual leadership. Thirdly, distributed leadership has empirical power albeit evidence from studies on distributed leadership is still emerging (Harris and Spillane, 2008).

Evidence from distributed leadership literature revealed that the construct was related to school goal achievement, teachers' professional development, instructional programme management (Obadara, 2013), teachers' organizational commitment (Hulpia et al., 2010), teacher morale and teacher enthusiasm (Sheppard et al., 2010), and school performance (Davis, 2009). Some other studies further promise a close link between distributed or collective forms of leadership and capacity building (Mitchell and Sackney, 2000), school improvement (Harris, 2004), organizational change (Harris et al., 2007), and professional learning communities (Morrissey, 2000). Considering the relatively small but compelling evidence from literature and arguments on distributed leadership, it might be expected that the notion of distributed leadership would be a significant variable for operating school processes. 


\subsection{The Relationship between Distributed Leadership and $O C B$}

Distributed leadership offers relatively new lenses to school leadership that invites multiple sources of participation, involvement, expertise, and contribution into leadership practices (Harris and Muijs, 2005). Teachers in schools where school leadership practices are distributed among faculty members are more likely to assume the responsibility of leadership tasks either with informal or formal roles such as head of department, guide, or mentor (Muijs and Harris, 2003). This probably results in extra roles and behaviors for teachers. Considering that OCBs denote to exerting more time and effort to influence school improvement and to build a positive school environment (DiPaola and Hoy, 2005), teachers can be expected to demonstrate more OCBs in schools where distributed leadership is prevalent instead of traditional leadership approaches. Similarly, Oplatka (2006) evidenced that a democratic and participative leadership style was one of the important determinants of OCB in schools. Jofreh et al. (2012) also found out that distributed leadership was significant variable in predicting teacher OCBs. Furthermore, Harris (2003) suggests that distributed leadership theory rests primarily upon collective responsibility and empowerment. A range of studies indicating that teachers' perceptions of their level of empowerment was significantly related to their OCBs (Bogler and Somech, 2004), that organizational collectivism was a strong predictor of teacher OCBs (Somech and Ron, 2007) and that collective efficacy was positively related to teachers' extra role behaviors (Somech and Drach-Zahavy, 2004) provide empirical support for the above argument. Therefore, the current study hypothesizes a positive relationship between OCB and distributed leadership; that is, the more the teachers' perceptions of distributed leadership, the more they exhibit OCBs.

\section{Method}

\subsection{Research Design}

This study employed a quantitative research methodology and designed in correlational research model to empirically examine the relationship between distributed leadership and OCB. Teachers' perceptions on distributed leadership in primary schools was the independent whereas OCB was the dependent variable of the study.

\subsection{Procedure and Participants}

A questionnaire with three parts was used to gather data in this study. The first part obtained personal information associated with such demographic variables of participants as gender, age, years in current school and total teaching experience. The second part of the questionnaire comprised of Distributed Leadership Scale to determine primary school teachers' perceptions of distributed leadership and the third part covered Organizational Citizenship Scale to measure primary school teachers' perceptions of OCBs. The researcher distributed the questionnaires to primary school teachers. Necessary instructions and explanations were printed at the beginning of the questionnaire and teachers were asked to complete the questionnaires voluntarily and anonymously. It was observed that each participant completed the questionnaire in about 6-8 minutes.

Respondents for this study were 258 teachers employed in 14 schools located in Kastamonu, Turkey. Out these teachers, $142(55 \%)$ were male and $116(45 \%)$ were female. The participants ranged in age from 24 to 53 with a mean of $34.67(\mathrm{SD}=6.59)$. The mean of years that participants spent in their current schools was $5.43(\mathrm{SD}=4.16)$ whereas the mean of total teaching experience of the participants was 10.45 years $(\mathrm{SD}=6.11)$.

\subsection{Measures}

Distributed Leadership Scale. This Likert-type scale developed by Özer and Beycioğlu (2013) included 10 items answered on a rating scale from "Never (1)" to "Always (5)". The validity and reliability analyses performed by Özer and Beycioğlu (2013) revealed that items related to distributed leadership yielded a single-factor structure. Factor loadings of the items varied between .70 and .82 , and a total of 10 items explained $58.26 \%$ of the variance in distributed leadership scores. The authors also concluded that the internal consistency coefficient of the scale was .92 with item-total correlations varying between .70 and .82 . In the present study, the results of explanatory factor analysis replicated the same factor structure as Özer and Beycioğlu's (2013). The scale consisted of ten items with factor loadings from .73 to .83 and accounted for $62.26 \%$ of the total variance. Furthermore, reliability coefficients calculated for the reliability of the scale were .93 while item-total correlations ranged from .70 to .78 .

Organizational Citizenship Behavior Scale (The OCB Scale). This scale was the refined form of Organizational Citizenship Behaviors in Schools Scale (The OCBS Scale) developed originally by DiPaola and Tschannen-Moran (2001) which included 15 items under single dimension and was answered on a rating scale from (1) "rarely occurs" to (4) "frequently occurs". However, The OCB Scale developed by DiPaola and Hoy (2005) composed of 12 items; 
10 positive and 2 negative items which were reversely encoded. It was adapted into Turkish by Taşdan and Yılmaz (2008). The adapted version of the scale was answered on a rating scale from "I totally disagree to (1)" to "I totally agree (5)". The validity and reliability analyses conducted by Taşdan and Yılmaz (2008) revealed that items associated with organizational citizenship yielded a single-factor structure. Factor loadings of the items varied between .31 and .82 , and a total of 12 items explained $45.66 \%$ of the total variance in organizational citizenship scores. The authors also found out that the internal consistency coefficient of the scale was .87 with item-total correlations ranging from .27 and .75 . The present study tested the validity and reliability of the Organizational Citizenship Behavior Scale. Results of the exploratory factor analysis (EFA) reproduced the same factor structure of Taşdan and Yilmaz (2008) except for two items excluded from the scale because of low factor loadings. Therefore, the scale included 10 items with factor loadings ranging from .37 to .78 and explained $39.63 \%$ of the total variance in organizational citizenship scores. Furthermore, reliability coefficients calculated for the reliability of the scale were .82 and item-total correlations varied from .29 to .67 .

\subsection{Data Analysis}

The researcher examined the missing or wrong data thoroughly before conducting analyses. The initial analyses were conducted to check the validity and reliability of the measures used in the current study. The subsequent analyses were performed to find out whether distributed leadership was significantly correlated with OCB and whether distributed leadership predicted teachers' perceptions on OCBs significantly. Therefore, mean scores were calculated by dividing the sums into the number of items in the scale, which helped to determine the perceptions of primary school teachers on distributed leadership and OCBs. Pearson product-moment correlation coefficients were then computed to find out the relationship between the study variables. The author then performed simple linear regression analysis to predict the dependent variable of the study by the independent variable. Beta $(\beta)$ coefficient and results for t-test were also considered to render the regression analysis results.

\section{Results}

\subsection{Correlations among Variables}

The means, standard deviations, and correlation coefficients among variables for all primary school teachers participating in the study are given in Table 1.

Table 1. Means, Standard Deviations, and Correlations among Variables for All Teachers

\begin{tabular}{lcccc}
\hline Variables & $\mathrm{X}$ & SD & 1 & 2 \\
\hline 1. Distributed leadership & 3.65 & .76 & - & .38 \\
2. Organizational citizenship & 3.70 & .58 & & - \\
\hline
\end{tabular}

Notes: $* p<.05 ; * * p<.01$

The means of distributed leadership and OCB in Table 1 mirrored that distributed leadership $(\bar{X}=3.65)$ was experienced by primary school teachers at a slightly higher level than OCB $(\bar{X}=3.70)$. As to the correlations in Table 1, there were positive and significant correlations between distributed leadership and teacher OCBs $(r=.38, p$ $<.01)$.

\subsection{Prediction of Teacher OCBS}

Table 2 indicates the results of simple linear regression analysis for variable predicting teacher OCBs.

Table 2. Results of Regression Analysis for Variables Predicting Teacher OCBs

\begin{tabular}{lccccc}
\hline Variables & $\mathrm{B}$ & $\mathrm{SE}$ & $\beta$ & $\mathrm{t}$ & $\mathrm{p}$ \\
\hline Constant & 2.66 & .17 & & 16.13 & .00 \\
Distributed leadership & .29 & .04 & .38 & 6.46 & .00 \\
\hline
\end{tabular}

Notes: $R=.38 ; R^{2}=14 ; F(1,256)=41.78 ; p<.00$

As can be seen from Table 2, a multiple $R$ of .38 explained nearly $14 \%$ of the variance in OCB scores. Findings revealed that distributed leadership was a positive and significant predictor of teacher OCBs $(\beta=.38, p<.05)$. This findings refers that distributed leadership is an important variable in explaining teacher OCBs. 


\section{Discussion}

The current study using distributed leadership as the predictor of teacher OCB supported the notion that distributed leadership was a significant and positive predictor of teacher OCB. This indicates that teachers exert OCBs more often in schools where distributed leadership is prevalent. This finding also refers that distributed leadership is one of the important variables that encourage teachers to perform OCBs. This finding is consistent with the previous limited research evidence indicating that distributed or participative leadership was a significant variable in predicting (Jofreh et al., 2012) and determining teacher OCBs (Oplatka, 2006).

This study revealed that distributed leadership was positively and significantly related to teacher OCBs. This finding denotes that teacher OCBs are more likely to increase when the responsibility of performing school leadership practices is distributed over faculty members. Distributed leadership refers to a different kind of leadership which welcomes the active and voluntary participation of multiple school actors including basically teachers (Harris and Muijs, 2005). This leadership approach enables teachers to work with colleagues on especially instructional issues and to improve teaching and learning environment of schools (DiPaola and Hoy, 2005) and promotes building human capacity of school for improvement (Harris, 2004). It is therefore suggested that teachers may find much more opportunities to perform OCBs when their contribution to and participation in school leadership practices is welcomed and supported. This finding of the study is also congruent with the opinions that teachers become motivated and encouraged to conduct projects, to help and support colleagues to go beyond minimum role expectations and to try out recent instructional methods or strategies when they are given opportunities to participate in decision-making processes and when their expertise and professionalism are respected (Oplatka, 2006). Thus, it is understandable why distributed leadership was positively correlated with teacher OCBs.

Results also indicated that distributed leadership was a positive and significant predictor of teacher OCBs. This is in line with the findings of a study conducted by Oplatka (2006) reporting that a democratic leadership style that enabled teachers to take an active role in decision-making processes was closely associated with teacher OCBs. Distributed leadership is a form of collective action that helps teachers develop their expertise by working with colleagues (Harris, 2004). This means that distributed leadership premises upon collaboration among colleagues and a sense of shared responsibility, which enables to build a healthy working environment for teachers to exert extra role behaviors. Evidence from several studies also indicated that teacher OCBs are likely to increase with a strong sense of organizational collectivism (Somech and Ron, 2007) and collective efficacy (Somech and Drach-Zahavy, 2004). The implication here is clear that the effectiveness and success of leadership practices depend heavily on teachers' involvement and skills (Harris and Lambert, 2003). In line with this argument, Leithwood and Mascall (2008) further purport that distributed leadership makes it possible for the organization to make well use of its members' expertise and qualifications to achieve organizational purposes as it promotes the participation in decision-making, learning from experiences, and being committed to organizational goals. Schools where teachers are provided with opportunities to perform leadership practices promote teachers' extra role behaviors that benefit both to the organization and the individual. It is therefore not surprising that distributed leadership is a strong predictor of teacher OCBs.

\section{Conclusion and Implications}

The present study concluded that distributed leadership predicted teacher OCBs positively and significantly. Teachers employed in schools where leadership practices are distributed over multiple individuals are more likely to perform OCBs. It is here needed to note that research on both distributed leadership and organizational citizenship is still evolving, which constituted a potential difficulty for the researcher to discuss the findings of the present study in relation to the related literature. For that reason, it should be suggested that more research evidence is required to better understand the constructs of distributed leadership and OCBs, their relationships, antecedents, and consequences for school settings. Researchers should focus more on examining and determining the various leadership styles such as teacher leadership to see whether they promote or inhibit teacher OCBs. Furthermore, future studies should investigate the relationships between OCB and other such potential organizational variables as commitment, trust, socialization, health, climate, and school academic optimism, and such personal qualities as psychological hardiness, coping with stress, and resistance to change. In future studies, schools' socioeconomic status should also be taken into consideration as an independent variable that may affect teachers' perceptions of OCBs.

DiPaola and Hoy (2005) suggest that a range of research is needed to clarify the factors that facilitate the development of OCBs and to learn to what extent organizational politics promote or prevent OCBs, to what extent the participative decision-making and teacher empowerment is important for the development of OCBs, and to find 
out the possible relationships between such demographic variables as gender, age, years in current school or total teaching experience and teacher OCBs. As the current study was a cross-sectional one, the longitudinal investigation of the relationships between distributed leadership practices and OCB by conducting some other research methods as interviews or document analysis is needed. This study centered upon the correlations and predictive relationships among distributed leadership and OCB. Therefore, the researcher conducted correlation and regression analyses. Future studies should deal with the causal relations between distributed leadership and teacher OCBs or other variables. Further studies should also study the contextual factors that support or inhibit distributed leadership in different samples by using qualitative or mixed research methods. Harris (2004) claims that the relations between distributed leadership and student achievement and learning are still not clear although the school improvement literature highlights the benefits of distributed and shared forms of leadership. Therefore, research would probably benefit from investigating the correlational, predictive, and causal relationships among distributed leadership and student outcomes.

Results of this study may appeal to school leaders, principals, practitioners, and teachers for building a school culture that enhances the distribution of leadership practices among faculty members, which in turn promotes teachers' going extra mile to contribute well to the school improvement process. Results from the present study may also provide policy makers with fruitful data to influence school effectiveness. Finally, it is required that factors that affect distributed leadership patterns and teacher OCBs within school context should be taken into consideration before designing educational programs aimed to help school administrators and teachers improve their qualifications.

\section{Limitations}

The present study has several limitations. First, the present study was conducted in order to examine the perceptions of primary school teachers on distributed leadership and OCBs. Thus, only primary school teachers responded to the items of the questionnaire. However, it may be argued that perceptions of other school community members such as school principals, vice principals, and parents are crucial for taking a clearer picture of the relationships between distributed leadership and OCBs. It is therefore suggested that further research examining the responses of teachers and administrators, and even students and parents on the variables of the current study should be conducted. Second, albeit early research on OCB (Organ, 1988, 1997; Organ and Lingl, 1995) identified five dimensions of the construct as discussed in the literature review section, the present study measured teacher OCBs with a single-factor scale following the argument that one dimension of the construct represents all aspects of OCB in schools which refers that the two aspects of OCB (benefit to the organization and benefit to the individual) fall into the same category in schools (DiPaola and Hoy, 2005). Evidence has already been found that there are not five dimensions of the construct of organizational citizenship and that one dimension represents all of OCBs within schools (DiPaola and Tschannen-Moran (2001), however, it should be noted that the construct validity of the Organizational Citizenship Behavior Scale is still under doubt. Upon considering that the Organizational Citizenship Behavior Scale was adapted into Turkish language and culture from a different context, this study suggests that there is a need for developing an original Organizational Citizenship Behavior Scale which represents the various dimensions of the construct and fits better to the Turkish educational context.

\section{References}

Altınkurt, Y., \& Yilmaz, K. (2012). Relationship between school administrators' organizational power sources and teachers' organizational citizenship behaviors. Educational Sciences: Theory \& Practice, 12(3), 1843-1852. http://dx.doi.org/10.1108/02621711211191005

Bennett, N., Wise, C., Woods, P. A., \& Harvey, J. A. (2003). Distributed leadership: A review of literature. National College for School Leadership. Retrieved June 1, 2014 from http://oro.open.ac.uk/8534/1/bennett-distributed-le adership-full.pdf

Bobbio, A., Van Dierendonck, D., \& Manganelli, A. M. (2012). Servant leadership in Italy and its relation to organizational variables. Leadership, 8(3), 229-243. http://dx.doi.org/10.1177/1742715012441176

Bogler, R., \& Somech, A. (2004). Influence of teacher empowerment on teachers' organizational commitment, professional commitment and organizational citizenship behavior in schools. Teaching and Teacher Education, 20, 277-289. http://dx.doi.org/10.1016/j.tate.2004.02.003

Cavazotte, F., Hartman, N. S., \& Bahiense, E. (2014). Charismatic leadership, citizenship behaviors, and power 
distance orientation: Comparing Brazilian and U.S. workers. Cross-Cultural Research, 48(1), 3-31. http://dx.doi.org/10.1177/1069397113494687

Chiu, S. F., \& Tsai, M. C. (2006). Relationships Among Burnout, Job Involvement, and Organizational Citizenship Behavior. The Journal of Psychology, 140(6), 517-530.

Christ, O., van Dick, R., Wagner, U., \& Stellmacher, J. (2003). When teachers go the extra mile: Foci or organizational identification as determinants of different forms of organizational citizenship behavior among schoolteachers. British Journal of Educational Psychology, 73, 329-341.

Davis, M. W. (2009). Distributed leadership and school performance (Doctoral dissertation). Retrieved from ProQuest Dissertations and Thesis database. (UMI: 3344534).

DiPaola, M. F., \& Hoy, W. K. (2005). Organizational citizenship of faculty and achievement of high school students. The High School Journal, 88(3), 35-44.

DiPaola, M. F., \& Tschannen-Moran, M. (2001). Organizational citizenship behavior in schools and its relationship to school climate. Journal of School Leadership, 11, 424-447.

Elmore, R. F. (2000). Building a new structure for school leadership. Washington, DC: The Albert Shanker Institute.

Emmerik, H. V., Jawahar, I. M., \& Stone, T. H. (2005). Associations among altruism, burnout dimensions, and organizational citizenship behaviour. Work \& Stress, 19(1), 93-100. http://dx.doi.org/10.1080/02678370500046283

Feather, N. T., \& Rauter, K. A. (2004). Organizational citizenship behaviours in relation to job status, job insecurity, organizational commitment and identification, job satisfaction and work values. Journal of Occupational and Organizational Psychology, 77, 81-94.

Fullan, M. (2001). Leading in a culture of change. San Francisco, CA: Jossey-Bass.

Gronn, P. (2000). Distributed properties. A new architecture for leadership. Educational Management \& Administration, 28(3), 317-338. http://dx.doi.org/10.1177/0263211X000283006

Gronn, P. (2009a). From distributed to hybrid leadership practice. In A. Harris (Ed.), Distributed school leadership (pp. 197-217). Dordrecht: Kluwer.

Gronn, P. (2009b). Leadership configuration. Leadership, 5(3), 381-394. http://dx.doi.org/10.1177/1742715009337770

Hargreaves, A., \& Fink, D. (2009). Distributed leadership: Democracy or delivery? In A. Harris (Ed.), Distributed leadership: Different perspectives (pp. 181-183). Netherlands: Springer.

Harris, A. (2003). Teacher leadership as distributed leadership: Heresy, fantasy or possibility? School Leadership \& Management, 23(3), 313-324. http://dx.doi.org/10.1080/1363243032000112801

Harris, A. (2004). Distributed leadership and school improvement: Leading or misleading? Educational Management Administration \& Leadership, 32(1), 11-24. http://dx.doi.org/10.1177/1741143204039297

Harris, A. (2008). Leading sustainable schools. Retrieved May 31, 2014 from http://www.bath.ac.uk/cree/Leading_Sustainable_Schools_130361.pdf

Harris, A., \& Lambert, L. (2003). Building leadership capacity for school improvement. Maidenhead, Philadelphia: Open University.

Harris, A., \& Muijs, D. (2005). Improving schools through teacher leadership. Maidenhead: Open University Press.

Harris, A., \& Spillane, J. P. (2008). Distributed leadership through the looking glass. Management in Education, 22(1), 31-34. http://dx.doi.org/10.1177/0892020607085623

Harris, A., Leithwood, K., Day, C., Sammons, P., \& Hopkins, D. (2007). Distributed leadership and organizational change: Reviewing the evidence. Journal of Educational Change, 8, 337-347. http://dx.doi.org/10.1007/s10833-007-9048-4

Hoy, W. K., Tarter, C. J., \& Kottkamp, R. B. (1991). Open schools/healthy schools: Measuring organizational climate. Newbury Park: SAGE Publications.

Hulpia, H., Devos, K., \& Van Keer, H. (2010). The influence of distributed leadership on teachers' organizational commitment: A multilevel approach. The Journal of Educational Research, 103, 40-52. http://dx.doi.org/10.1080/00220670903231201 
Jofreh, M., Mohammadi, F., \& Yasini, A. (2012). Leadership distribution consequences in schools: A particular look at organizational citizenship behavior of teacher. Australian Journal of Basic \& Applied Sciences, 6(12), 259-268.

Lashway, L. (2003). Distributed leadership. ERIC Clearinghouse on Educational Management, Research Roundup, 19(4), 3-5. Retrieved June 1, 2014, from http:// files.eric.ed.gov/fulltext/ED477356.pdf

Leithwood, K., \& Mascall, B. (2008). Collective leadership effects on student achievement. Educational Administration Quarterly, 44(4), 529-561. http://dx.doi.org/10.1177/0013161X0832122

Lian, L. K., \& Tui, L. G. (2012). Leadership styles and organizational citizenship behavior: The mediating effect of subordinates' competence and downward influence tactics. Journal of Applied Business and Economics, 13(2), 59-96.

López-Domínguez, M., Enache, M., Sallan, J. M., \& Simo, P. (2013). Transformational leadership as an antecedent of change-oriented organizational citizenship behavior. Journal of Business Research, 66, $2147-2152$. http://dx.doi.org/10.1016/j.jbusres.2013.02.041

Mitchell, C., \& Sackney, L. (2000). Profound improvement. Building capacity for a learning community. Lisse, The Netherlands: Swets \& Zeitlinger.

Moorman, R. H. (1991). Relationship between organizational justice and organizational citizenship behaviors: Do fairness perceptions influence employee citizenship? Journal of Applied Psychology, 76(6), 845-855.

Morrissey, M. S. (2000). Professional learning communities: An ongoing exploration. Austin, TX: Southwest Educational Development Laboratory. Retrieved June $1, \quad 2014 \quad$ from http://www.willettsurvey.org/TMSTN/PLCs/plc-ongoing.pdf

Muijs, D., \& Harris, A. (2003). Teacher leadership-Improvement through empowerment? An overview of the literature. Educational Management Administration \& Leadership, 31(4), 437-448. http://dx.doi.org/10.1177/0263211X030314007

Nguni, S., Sleegers, P., \& Denessen, E. (2006) Transformational and transactional leadership effects on teachers' job satisfaction, organizational commitment, and organizational citizenship behavior in primary schools: The Tanzanian case. School Effectiveness and School Improvement, 17(2), 145-177. http://dx.doi.org/10.1080/09243450600565746

Obadara, O. E. (2013). Relationship between distributed leadership and sustainable school improvement. International Journal of Educational Sciences, 5(1), 69-74.

Ogawa, R. T., \& Bossert, S. T. (2000). Leadership as an organizational quality. In The Jossey-Bass Reader On Educational Leadership, pp. 38-58. San Francisco: Jossey-Bass.

Ölçüm-Çetin, M. (2004). Örgütsel vatandaşlık davranışı [Organizational citizenship behavior]. Ankara: Nobel.

Oplatka, I. (2006). Going beyond role expectations: Toward An understanding of the determinants and components of teacher organizational citizenship behavior. Educational Administration Quarterly, 42(3), 385-423. http://dx.doi.org/10.1177/0013161X05285987

Organ, D. W. (1988). Organizational citizenship behavior: The good soldier syndrome. Lexington, MA: Lexington Books.

Organ, D. W. (1997). Organizational citizenship behavior: It's construct clean-up time. Human Performance, 10(2), 85-97. http://dx.doi.org/10.1207/s15327043hup1002_2

Organ, D. W., \& Lingl, A. (1995). Personality, Satisfaction, and Organizational Citizenship Behavior. The Journal of Social Psychology, 135(3), 339-350.

Özer, N., \& Beycioğlu, K. (2013). The development, validity and reliability study of distributed leadership scale. Elementary Education Online, 12(1), 77-86.

Paine, J. B., \& Organ, D. W. (2000). The cultural matrix of organizational citizenship behavior: Some preliminary conceptual and empirical observations. Human Resource Management Review, 10(1), 45-59.

Podsakoff, P. M., MacKenzie, S. B., \& Bommer, W. H. (1996). Transformational leader behaviors and substitutes for leadership as determinants of employee satisfaction, commitment, trust, and organizational citizenship behaviors. Journal of Management, 22(2), 259-298. 
Podsakoff, P. M., MacKenzie, S. B., Moorman, R. H., \& Fetter, R. (1990). Transformational leader behaviours and their effects on followers' trust in leader, satisfaction, and organizational citizenship behaviours. Leadership Quarterly, 1(2), 107-142.

Podsakoff, P. M., MacKenzie, S. B., Paine, J. B., \& Bachrach, D. G. (2000). Organizational citizenship behaviors: A critical review of the theoretical and empirical literature and suggestions for future research. Journal of Management, 26(3), 513-563.

Schepman, S. B., \& Zarate, M. A. (2008). The relationship between burnout, negative affectivity and organizational citizenship behavior for human services employees. International Journal of Humanities and Social Sciences, 2(4), 216-221.

Schnake, M. E., \& Dumler, M. P. (2003). Levels of measurement and analysis issues in organizational citizenship behaviour research. Journal of Occupational and Organizational Psychology, 76, 283-301. http://dx.doi.org/10.1348/096317903769647184

Sezgin, F. (2005). Örgütsel vatandaşlık davranışları: Kavramsal bir çözümleme ve okul açısından bazı çıkarımlar [Organizational citizenship behaviors: A conceptual analysis and some inferences for the schools]. Gazi University Journal of Gazi Educational Faculty, 25(1), 317-339.

Sezgin, F. ve Kılınç, A. Ç. (2012). İlköğretim okulu öğretmenlerinin mesleki tükenmişlik düzeyleri ile örgütsel vatandaşlık davranışları arasındaki ilişki [The relationship between primary school teachers' professional burnout and organizational citizenship behaviors]. Ahi Evran University Journal of Kirşehir Education Faculty, 13(3), 103-127.

Sheppard, B., Hurley, N., \& Dibbon, D. (2010, May). Distributed leadership, teacher morale, and teacher enthusiasm: Unravelling the leadership pathways to school success. Paper presented at American Educational Research Association, Denver, Colorado.

Somech, A., \& Drach-Zahavy, A. (2004). Exploring organizational citizenship behaviour from an organizational perspective: The relationship between organizational learning and organizational citizenship behaviour. Journal of Occupational and Organizational Psychology, 77, 281-298.

Somech, A., \& Ron, I. (2007). Promoting organizational citizenship behavior in schools: the impact of individual and organizational characteristics. Educational Administration Quarterly, 43(1), 38-66. http://dx.doi.org/10.1177/0013161X06291254

Song, J. H., Kang, I. G., Shin, Y. H., \& Kim, H. K. (2012). The impact of an organization's procedural justice and transformational leadership on employees' citizenship behaviors in the Korean business context. Journal of Leadership \& Organizational Studies, 19(4), 424-436. http://dx.doi.org/10.1177/1548051812446659

Spillane, J. P (2006). Distributed leadership. San Francisco: Jossey-Bass.

Spillane, J. P. (2005). Distributed leadership. The Educational Forum, 69(2), 143-150.

Spillane, J. P., Diamond, J. B., \& Jita, L. (2003). Leading instruction: The distribution of leadership for instruction. Journal of Curriculum Studies, 35(5), 533-543.

Spillane, J. P., Halverson, R., \& Diamond, J. B. (2001). Investigating school leadership practice: A distributed perspective. Educational Researcher, 30, 23-28.

Taşdan, M., \& Y1lmaz, K. (2008). Organizational citizenship and organizational justice scales' adaptation to Turkish. Education and Science, 33(150), 87-96.

Tsui, K. T., \& Cheng, Y. C. (1999). School organizational health and teacher commitment: A contingency study with multi-level analysis. Educational Research and Evaluation: An International Journal on Theory and Practice, 5(3), 249-268. http://dx.doi.org/10.1076/edre.5.3.249.3883

van Dick, R., Grojean, M. W., Christ, O., \& Wieseke, J. (2006). Identity and the extra mile: relationships between organizational identification and organizational citizenship behaviour. British Journal of Management, 17, 283-301. http://dx.doi.org/10.1111/j.1467-8551.2006.00520.x 